\title{
Social Capital and Political Participation: Understanding the Dynamics of Young People's Political Disengagement in Contemporary Britain
}

\author{
Matt Henn*, Mark Weinstein ${ }^{* *}$ and Sarah Hodgkinson*** \\ * Graduate School College of Business, Law and Social Sciences, Nottingham Trent University, Nottingham \\ E-mail: matt.henn@ntu.ac.uk \\ ** Graduate School College of Business, Law and Social Sciences, Nottingham Trent University, Nottingham \\ E-mail: mark.weinstein@ntu.ac.uk \\ ***Department of Criminology, University of Leicester, Leicester \\ E-mail: sf101@leicester.ac.uk
}

Only 37 per cent of young people voted at the 2005 British General Election, seemingly confirming the oft-cited view that this generation is becoming increasingly disconnected from the political process. Results from a nationwide survey, however, indicate that their withdrawal from formal politics is more a result of their scepticism of the way the political system operates, than apathy. Furthermore, they are diverse in their political (dis)engagement. Results from an examination of the relative effects of socio-economic location and social capital are inconclusive, although the data indicate that government social policy aimed at mobilising social capital and addressing socio-economic issues may increase civic engagement.

\section{Social Capital and Political Engagement}

Social capital is a contested concept, with many different approaches to how it is defined and how it is measured (Coleman, 1988; Halpern, 1999; Hall, 1999; Putnam, 2000). However, most observers would agree that at its broadest, social capital refers to the social networks between individuals as well as the trust, shared norms and reciprocities that underpin and in turn arise from such connections (Putnam, 2000).

The existence or not of social capital is considered to have implications for political life and the general health of democracies. According to Putnam (1993), successful and efficient democratic systems are most likely to be found in tolerant and cooperative societies displaying high levels of associational life and trust amongst their citizens; by contrast, governments in societies relatively lacking in social capital are likely to demonstrate greater inefficiency and corruption. Thus, it can be argued that where people feel isolated and alienated from social networks and wider society, this will impact negatively on their levels of trust in others and in political processes, institutions and representatives - potentially leading to a breakdown in civic engagement (Newton, 1999a; Foley and Edwards, 1996). ${ }^{1}$ In such contexts, people's withdrawal from formal political life may be observed both in terms of their decline in support for, and membership of, political organisations (including parties), and of their abstention from voting in elections (Henn et al., 2005).

Conversely, where people feel relatively high degrees of trust in others and have integrated links within communities through membership of local associational groups, 
a virtuous circle may develop; a more positive pre-disposition toward political processes and institutions leads individuals to have a greater confidence in the efficacy of political participation (Hall, 1999). Consequently, it has been argued that where social capital can be shaped, developed and mobilised by social policy, this may have positive outcomes both in terms of civic engagement and better government (Hall, 1999; Halpern, 1999; Newton, 1999b). As Lowndes and Wilson (2001: 636) contest:

In addition to shaping the context within which established associations flourish or decline, the institutional design of local governance may influence prospects for the formation of new groups and new stocks of social capital. By providing opportunities for participation, local agencies can influence citizens' appetites for, and competence in, civic activity.

\section{Youth and political (dis)engagement in Britain}

However, the evidence in contemporary Britain would seem to indicate that a rift is developing between government and citizens, with people seemingly withdrawing from the democratic process. This is particularly apparent in terms of declining voter turnout rates which are a major issue across the generations in Britain (Electoral Commission, 2005a; Electoral Commission and the Hansard Society, 2006; Power Inquiry, 2006). For instance, at the 1997 General Election, 71 per cent of voters took to the polls, but by the following contest in 2001, turnout had slumped to its lowest level since 1918 - to only 59 per cent of the eligible electorate (Whiteley et al., 2001). Even with the introduction of postal voting in 2005, the polling rate increased by only 2 per cent (Electoral Commission, 2005a).

This political disconnection amongst British citizens is particularly acute amongst young people, and patterns of political behaviour and civic engagement amongst this age group have recently attracted much attention, largely because of their increasing abstention in elections (Russell et al., 2002; O'Toole et al., 2003; Phelps, 2005). Turnout in elections is much lower for this youth generation than it is for older members of the electorate. Compared with the rates reported above, only 39 per cent of eligible 18 to 24 year olds voted at the 2001 General Election (reduced from 68 per cent in 1997), falling further to only 37 per cent in 2005. In support of this generational turnout gap, Franklin (2004) has conducted an extensive international analysis of electoral trends and concluded that age in Britain as in many other countries is a significant predictor of turnout. Indeed, he claims that the extension of the vote to younger adults which took place in several countries after the mid-1960s came with a cost which typically depressed electoral turnout rates.

Furthermore, many academic studies conclude that young people have comparatively lower-levels of political knowledge than their older contemporaries (Park, 2000; O'Toole et al., 2003), and have a distinct lack of interest in (formal) politics (Heath and Park, 1997). Compared with older adults, they are less likely to be politically active (The Electoral Commission and The Hansard Society, 2006), display comparatively weaker commitments to political parties (Parry et al., 1992), and are less likely to be members of such organisations (Cole, 1997). Indeed, the message from many such studies is that young people's levels of political participation in general are in decline, and at a somewhat more rapid rate than is the case for older adults and previous youth cohorts (Pirie and Worcester, 1998 and 2000; Russell et al., 2002). Moreover, young people can be differentiated from wider society in terms of their political views - they are considered to be less conservative 
than older contemporaries, highly disillusioned with the operation of politics, and more sceptical of politicians (Wring, Henn and Weinstein, 1999).

As a consequence, there is a concern amongst politicians and officials that this age group have a disaffection from politics that is deeply entrenched, and that in the medium to long term, the more civic-oriented older generations will be replaced by this younger sceptical generation, threatening the legitimacy of the political system itself (Jowell and Park, 1998; Phelps, 2004; Electoral Commission and the Hansard Society, 2006).

A number of recent studies have challenged the predominant political apathy thesis, arguing instead that young people are interested in political matters, and do take part in differing forms of political action (White et al., 2000; Norris, 2003; O'Toole et al., 2003; Henn and Weinstein, 2006). Nonetheless, the central preoccupation with young people's falling election turnout rates persists, as do concerns therefore about their decoupling from the British democratic process. ${ }^{2}$

\section{Understanding political (dis)engagement in Britain}

Conventional explanations of political participation have tended to focus upon people's socio-economic characteristics, such as their social class, gender, ethnicity, and educational attainment (Verba and Nie, 1972; Parry et al., 1992). Recently, a report published by The Electoral Commission (2005b) has identified a link between social exclusion and both political participation and electoral participation. Nonetheless, results from other studies indicate that these factors have diminishing influence upon people's political behaviour (see for instance, Leighley, 1995, and Pattie et al., 2004). The linked civic voluntarism model tends to stress the importance of resources that individual's have at their disposal, including the time, money, and the opportunities that they have to participate in politics - resources that may be structured by their socio-economic background (Verba et al., 1995).

By way of contrast, social capital is a relatively under-explored potential driver of political participation in Britain, although recently several studies have been published which reveal a positive relationship between social capital variables and civic engagement (Hall, 1999; Pattie et al., 2003; Fahmy, 2004). While Putnam $(1995,2000)$ has argued that social capital is on the decline in the United States, the situation is somewhat different in Britain. Hall claims that although there is less research in the area, such evidence as exists indicates that 'aggregate levels of social capital have not declined to an appreciable extent in Britain over the post-War years' (Hall, 1999, p. 457). Moreover, in their book, Citizenship in Britain, Pattie et al. claim that the relationship between social capital and both election turnout and civic attitudes is significant (2004). ${ }^{3}$

In this article, we intend to examine and compare the relative importance of young people's socio-economic characteristics with their social capital in order to account for patterns in their political and civic engagement. ${ }^{4}$ Whilst social capital is often characterised as a potential panacea for this declining political participation and deepening political distrust, the link between the two remains relatively under-explored as far as the study of young people is concerned. Consequently, research into this area is important for the future health of British democracy, as this relatively disconnected age group take the place of older, more engaged citizens; if social capital is found to increase young people's political engagement, then government can contribute to democratic well-being by initiating appropriate social policies for enhancing social capital. 


\section{Research design}

This study is based on a nationwide survey of attainers - young people who have just been entered on the electoral register and who are therefore eligible to vote in an election for the first time. Conducted in 2002, this is the first large-scale study to focus exclusively on this group.

In this article we perform disaggregated analyses of this group in order to examine whether there are any notable differences between youth sub-groups in terms of their political attitudes. This stands in contrast to the traditional focus on young people's engagement with the political process, where youth have been marginalised or 'hidden' in mainstream social science research, often being subsumed into a homogeneous and undifferentiated group. ${ }^{5}$ In particular, we are interested in the following questions: (a) whether or not young people are politically disconnected, and, if so, what is the source of this - political apathy or political scepticism?; (b) whether or not there are any identifiable differences in terms of young people's general levels of satisfaction with British democracy; (c) whether or not young people feel that there are opportunities open to them to meaningfully participate within, and influence, the political process; (d) whether or not there is any variation in their enthusiasm for (or scepticism of) the political set-up; (e) and if such variations exist across different youth sub-groups, what are their sources are socio-economic factors and social capital important drivers of young people's political (dis)engagement in Britain? These are important questions, the answers to which will help to increase our understanding of the dynamics of youth political attitudes in Britain - of a group that is subject to much criticism for its (alleged) high levels of political apathy and disinterest, but relatively little systematic empirical investigation.

\section{Data collection methods}

We used a random sampling method for our study, with respondents drawn from the electoral register. ${ }^{6}$ The sample was stratified by Government Standard Region, and within that by ACORN, ${ }^{7}$ securing a geographically and socio-economically representative sample. Respondents were mailed a questionnaire direct to their home addresses during early 2002, with 705 returns from 3109 sent out - resulting in a final response rate of 23 per cent, which represents a satisfactory return for a postal survey of this nature. Whilst a higher response rate would have been preferred, the important issue in terms of representativeness is not the proportion of non-respondents, but the degree to which the survey respondents are a reflection of the wider youth population (Oppenheim, 1992: 102). With this in mind, we then weighted data to take account of the distribution of the British youth population across the key variables of region (and nationality), gender, social class, and ethnicity. Tests confirmed that there was a high degree of match between the weighted and unweighted data, indicating that our survey results have high external validity and generalisability. ${ }^{8}$

\section{Methods of analysis}

In order to examine differences in political orientation amongst different youth sub-groups and the overall impact of key variables on young people's political attitudes, multivariate logistic regression has been used. Two sets of predictor (independent) variables were 
deployed for this purpose. The first were socio-economic in nature, including ethnicity, gender, social class, and education (qualifications held, and whether respondents remained in full-time education). ${ }^{9}$ These variables have been selected because previous studies indicate that they are associated with political attitudes and levels of political participation, ${ }^{10}$ and we wanted to test the usefulness of this traditional social science approach in assessing young people's orientation to politics. The second set of predictor variables were designed to measure the impact of social capital on young people's political engagement. Social capital is measured using two indexes. The first comprises respondents' trust in other people. ${ }^{11}$ The second index is based on their associational membership (participation in local voluntary activity and community groups). ${ }^{12}$

\section{Results}

So how can we best understand the dynamics of youth political orientation in Britain-by reference to key socio-economic variables (the conventional social science approach), or by an examination of the two social capital-based variables? In order to address this question, we conducted a series of direct binary logistic regressions in which the dependent variables mentioned earlier ${ }^{13}$ were tested against (i) the five socio-economic predictors, and (ii) the two social capital variables (trust and associational membership). ${ }^{14}$ Table 1 presents the results derived from these analyses.

\section{Political engagement}

Far from being uniformly apolitical and apathetic, a substantial proportion of young people stated that they had an interest in 'Politics' (56 per cent), and nearly half (48 per cent) claimed an interest in the 2001 General Election held a year before our study. By combining the data from these and a number of similar questions answered in our survey, we were able to derive a 'political interest' variable which we tested against the socio-economic variables outlined above. Table 1 reveals evidence of a statistically significant gender gap, with men over twice as likely as women to profess an interest in politics $(\operatorname{Exp}(\beta)$ value of 2.05). Social class also exerted a statistically significant influence-young people from middle-class managerial/professional households were significantly more interested in politics than those from manual, unskilled or working-class households $(\operatorname{Exp}(\beta) 1.818)$.

Educational history is not an especially strong driver of political interest, however. Those who had chosen to prolong full-time study were more interested in political affairs than those who had left full-time study at the statutory school leaving age, but the difference is not a significant one; whether or not young people hold educational or work-related qualifications has no appreciable effect. Ethnicity is an interesting case. The $\operatorname{Exp}(\beta)$ value is relatively high (1.974), indicating that young people from black minority ethnic (BME) groups are almost twice as likely to be interested in Politics than are white youth. However, the $\beta$ value indicates that this difference is not statistically significant. This may be partly due to the uneven distribution of cases within this variable, and the relatively small size of the BME group (33 respondents, representing 4.7 per cent of the full sample).

Just as the impact of socio-economic background on young people's political interest is mixed, so also appears to be the effect of social capital. Those with social trust in others were nearly one and a half times more likely to claim an interest in politics than were 
Table 1 Logistic regression models of socio-economic and social capital variables as predictors of political attitudes

\begin{tabular}{|c|c|c|c|}
\hline & $\beta$ & Wald & $\operatorname{Exp}(\beta)$ \\
\hline \multicolumn{4}{|l|}{ Interest } \\
\hline Sex (Being male) & $0.718^{*}$ & 5.686 & 2.050 \\
\hline Ethnicity (Being non-white) & 0.680 & 0.745 & 1.974 \\
\hline Qualifications (Having no qualifications) & 0.118 & 0.024 & 1.125 \\
\hline In education (Staying in education) & 0.383 & 1.388 & 1.467 \\
\hline Social class (Being managerial/professional) & $0.598^{*}$ & 4.106 & 1.818 \\
\hline Social capital - Trust (Having trust) & 0.382 & 1.448 & 1.465 \\
\hline Social capital - Associational membership (volunteered) & 0.973 & 2.563 & 2.645 \\
\hline Nagelkerke $\mathrm{R}^{2}$ & 0.126 & & \\
\hline \multicolumn{4}{|l|}{ Democracy } \\
\hline Sex (Being male) & 0.576 & 3.349 & 1.778 \\
\hline Ethnicity (Being white) & 0.198 & 0.046 & 1.219 \\
\hline Qualifications (Having no qualifications) & 0.386 & 0.216 & 1.471 \\
\hline In education (Staying in education) & $0.870^{*}$ & 5.553 & 2.387 \\
\hline Social class (Being managerial/professional) & $0.671^{*}$ & 4.542 & 1.957 \\
\hline Social capital - Trust (Having trust) & 0.467 & 2.045 & 1.595 \\
\hline Social capital - Associational membership (volunteered) & 0.261 & 0.177 & 1.299 \\
\hline Nagelkerke $\mathrm{R}^{2}$ & 0.135 & & \\
\hline \multicolumn{4}{|l|}{ Efficacy } \\
\hline Sex (Being male) & 0.640 & 1.813 & 1.859 \\
\hline Ethnicity (Being non-white) & 0.130 & 0.013 & 1.139 \\
\hline Qualifications (Having no qualifications) & $1.842^{*}$ & 5.016 & 6.307 \\
\hline In education (Staying in education) & 0.575 & 0.905 & 1.777 \\
\hline Social class (Being managerial/professional) & 0.472 & 0.924 & 1.604 \\
\hline Social capital - Trust (Having trust) & 0.150 & 0.088 & 1.162 \\
\hline Social capital - Associational membership (not volunteered) & 0.620 & 0.552 & 1.859 \\
\hline Nagelkerke $\mathrm{R}^{2}$ & 0.086 & & \\
\hline \multicolumn{4}{|l|}{ Party } \\
\hline Sex (Being male) & 0.164 & 0.124 & 1.179 \\
\hline Ethnicity (Being white) & 0.084 & 0.005 & 1.088 \\
\hline Qualifications (Having no qualifications) & 0.953 & 1.061 & 2.595 \\
\hline In education (Staying in education) & 1.042 & 2.602 & 2.835 \\
\hline Social class (Being managerial/professional) & 0.807 & 2.636 & 2.242 \\
\hline Social capital - Trust (Having trust) & $1.129^{*}$ & 5.726 & 3.092 \\
\hline Social capital - Associational membership (volunteered) & 0.409 & 0.134 & 1.506 \\
\hline Nagelkerke $\mathrm{R}^{2}$ & 0.164 & & \\
\hline
\end{tabular}

Notes: Some variables (e.g., ethnicity and associational membership) have been recoded in the opposite direction in some of the analyses to make interpretation of findings more coherent as it is well recognised that negative $\operatorname{Exp}(\beta)$ s are more difficult to interpret size of effect. The direction of the coding is, however, made explicit in the table.

${ }^{*} \mathrm{p}<05,{ }^{* *} \mathrm{p}<.01,{ }^{* * *} \mathrm{p}<.001$.

those lacking such trust $(\operatorname{Exp}(\beta)$ 1.465). Similarly, marked differences in political interest appear to exist between those with some associational membership who were nearly three times more politically engaged than those not volunteering for such activity. Despite the 
high $\operatorname{Exp}(\beta)$ (2.645), the impact is not statistically significant for this variable-possibly as a consequence of the under-weighted category for those reporting no associational membership (only 22 respondents, representing 3.1 per cent of the full sample).

Overall, these results seem to run counter to popular thinking that young people are inherently dismissive of 'Politics'. British youth do profess an interest in the world of political affairs. However there are some important differences across youth sub-groups in this respect, although the results are somewhat mixed for both socio-economic and social capital effects.

\section{Support for the democratic process}

Despite the concerns of many politicians, policy-makers, journalists and academics about young people's apparent disregard for politics, this generation does appear to have support for the democratic process. The data from our survey reveal that more people said they were satisfied (31 per cent) than were dissatisfied (26 per cent) with the way democracy works (although 28 per cent held a non-committal 'Neither Satisfied Nor Dissatisfied' view, suggesting that in combination with the detractors the majority of attainers were dissatisfied or ambivalent about the democratic process). However, there were some important distinctions in views held between different youth groups. Those remaining in full-time education, and those from middle-class households all displayed higher than expected support for the notion of democracy in Britain; by contrast those young people who had left the educational system, and those from predominantly workingclass households were less enthusiastic about British democracy. The effect of these two socio-economic variables is statistically significant (with $\operatorname{Exp}(\beta)$ values of 2.387 and 1.957 respectively). Gender and ethnicity display less of an impact on young people's attitudes to the democratic process, although men and white youth were more likely to express support than were women or those from BME groups. Interestingly, and perhaps contrary to expectations, the data indicate that those not in possession of educational qualifications seem to be more interested in politics than their more qualified counterparts, although the difference is also not a significant one.

The impact of the two social capital variables on young people's political outlook is relatively marginal. Whether or not young people participated in voluntary or local community groups seemed to have little influence over their satisfaction with the state of democracy in Britain - those engaging in such activity held similar views to the 'inactives'. Social trust seems to exert a greater effect than does associational membership $(\operatorname{Exp}(\beta)$ value 1.595 compared to 1.299 ), but this is not statistically significant.

\section{Political efficacy}

By combining five different questions from our survey we created an external efficacy index. The data indicate that young people had low feelings of political efficacy - an overwhelmingly large majority considered themselves to be uniformly marginalised from the political process, and relatively powerless to influence it (89 per cent). There were no significant observable differences according to respondents' ethnicity, their social class or whether or not they have remained in full-time education. As was the case with the Democracy variable reported in the previous section, those not in possession of 
educational or work-related qualifications seem to be more politically engaged than their more qualified contemporaries; they are significantly more likely to feel that they have some influence over the political decision-making world, by a margin of more than six to one $(\operatorname{Exp}(\beta)$ 6.307). This would seem to contradict previous academic studies which suggest a positive relationship between educational attainment and political efficacy (e.g., Parry et al., 1992).

Neither of the two social capital variables has a significant influence on feelings of external efficacy. At most, there are only small to moderate effects observed in the data. Furthermore, the effects of these two social capital indexes are not uniform. Trust in other people exerts less of an impact on young people's feelings of political efficacy $(\operatorname{Exp}(\beta)$ 1.162 ) than does their participation in local voluntary or community groups. Interestingly, and contrary to expectations to be inferred from the social capital literature, inactive youth appear to be almost twice as optimistic as are their active counterparts $(\operatorname{Exp}(\beta)$ 1.859). However, the difference observed for this associational membership variable is not statistically significant.

\section{Perception of political parties and professional politicians}

Finally, we examined young people's attitudes towards the political parties and professional politicians. A summary variable was developed for this purpose, and the data indicate that all of the youth groups in the study had a deeply negative view of these political players. There was no evidence of any gender gap or of any notable difference in views according to young people's ethnicity. In contrast, social class would appear to be quite an important driver of political trust, with those young people from middle-class households reporting much less scepticism than their manual, unskilled or working-class counterparts $(\operatorname{Exp}(\beta)$ 2.242). Again, educational career seems to have a contradictory effect. Those remaining in full-time education demonstrated less aversion to the political parties than did those no longer in education $(\operatorname{Exp}(\beta) 2.835)$. However, once again educational attainment seems to display an effect that is contradictory to what we might expect from the literature on political engagement; those with no qualifications were less critical of these political players than more qualified youth $(\operatorname{Exp}(\beta) 2.595)$. Despite some of the differences reported amongst youth sub-groups, for each of the socio-economic variables examined, all groups were overwhelmingly critical of professional politicians and the political parties; any differences observed were not statistically significant.

Interestingly those young people with high levels of social capital also held a deep dislike of formal professional politics. Those active in local voluntary and community groups were less hostile than were those with no such experience, although the difference noted was relatively modest $(\operatorname{Exp}(\beta) 1.506)$. Perhaps not surprisingly, there appears to be a strong and significant link between social trust and political trust $(\operatorname{Exp}(\beta) 3.092)$ which has been observed in other studies (Hall, 1999). Nonetheless, even those attainers exhibiting high levels of social trust have little faith in those who are charged with conducting politics on their behalf.

\section{Conclusion}

In this article, we have presented evidence to suggest that young people are interested in 'Politics' and do have some faith in the democratic process. Nonetheless, it would appear 
that the political system and the established parties and politicians that dominate it, are together failing to provide the stimuli necessary to encourage young people to engage with politics. Consequently, they are becoming increasingly disenchanted with all that the traditional political set-up has to offer.

We have also found that there is no uniform youth approach to politics in Britain this generation is diverse in its political outlook. Whilst there are minimal ethnicity effects, there is some evidence of a gender gap when it comes to political attitudes. However, this gender dimension has less influence than does social class or educational career. Those from predominantly middle-class households appear to be much more committed to the democratic process than are young people from broadly working-class backgrounds. Whilst they too hold an antipathy towards the political parties and the professional politicians, they are noticeably less sceptical than are their working-class contemporaries.

Education also has some influence on young people's political outlook. Surprisingly, those in possession of educational or work-related qualifications are less likely than those without to feel that they have some influence over the political decision-making world, and they are more hostile to the political parties and politicians. Perhaps the educational capital that they have built up through studying for these qualifications has sensitised them to the vagaries of the political system? Or it might be argued perhaps that those with no qualifications are more likely to have left education, found employment, and started earning - if so, this is likely to boost their sense of personal autonomy relative to those still in education. However, our data suggest that those without educational or work-related qualifications are only marginally more likely to be in paid work than are their qualified peers. By way of contrast, the effect of remaining in the education system would appear to exert significant influence - staying on in the education system has a clear and consistent impact on attitudes to the democratic system and the dominant political actors.

Social capital has at best a mixed impact on political attitudes, and certainly this is not more significant than are socio-economic differences. Those lacking in social capital have less faith in the democratic process and its custodians than do their counterparts who have relatively higher levels of social capital. But these differences are not strong. Associational membership has only a negligible impact on political interest (although this is not statistically significant). Social trust is only statistically significant in terms of its impact on trust in political parties and professional politicians - nonetheless, all young people are deeply sceptical of these key political players. There is no discernible impact of social capital on either faith in the democratic process or feelings of political efficacy. The overall direct influence of social capital as a driver of youth political disengagement in Britain is therefore questionable, especially when compared with the impact of key socio-economic variables such as social class and education.

These results suggest therefore that government social policy which addresses socioeconomic-related issues, educational policy, and the mobilisation of social capital may have some impact on young people's civic engagement. This is particularly pertinent given that studies published elsewhere indicate that young people in particular are more likely to experience greater levels of social exclusion and have less social capital than older age groups. They are less trusting of others, and less well integrated within communities with fewer social networks (Hall, 1999; Fahmy, 2004; Lowndes and Wilson, 2001). Policy which succeeds in expanding educational participation, reducing social class differences and social exclusion, regenerating neighbourhoods and communities, strengthening local community networks and promoting social cohesion, and fostering volunteering and 
self-help, may contribute in helping to at least limit the drift towards further political disengagement amongst youth in Britain.

\section{Acknowledgements}

This research was supported by the Economic and Social Research Council, award R000223598: First-Time Voters' Attitudes towards Party Politics in Britain. We would like to thank the ESRC for this support. We would also like to express our thanks to Rob Vickers and Neil Conant at Nottingham Trent University, both for their preparation of the data and for their general contribution to the project.

\section{Notes}

1 However, see for instance Newton (1999a) who claims that the evidence from Britain is that the links between social trust and political behaviour are relatively weak and contingent.

2 For a review of the debate, see Henn et al. (2005).

3 However, it should be noted that the evidence is at times contradictory, and dependent on how social capital and political activity are measured. For instance, Pattie et al. (2004) claim that trust in other people is positively related to election turnout (and significantly so), whilst associational membership (of voluntary groups) discourages voting. However, elsewhere the same authors (Pattie et al., 2003) claim that trust in others is negatively related (and significantly so) to other forms of civic activism - the contacting of officials and collective action such as taking part in demonstrations.

4 One other model that has attained significant prominence in the study of political participation is the rational choice model, which posits that, 'individuals engage in political activity to pursue particular goals, and they decide to participate when the benefits of such activity outweigh the costs' (Leighley, 1995: 192). However, an examination of this model is beyond the scope of our survey data and therefore of this article.

5 See research by Weinstein (2005) where it is argued that historically social science research has employed a concept of 'youth' for the study of political attitudes and political behaviour that fails to appreciate the varied experiences of young people that flow from their social class, gender, ethnicity and other key socio-economic characteristics.

6 Of course, not every attainer may be captured by this method - indeed, approximately 15 per cent of attainers are not registered to vote (Russell et al., 2002). Nonetheless, the vast majority of our target group were eligible for inclusion.

7 This enabled respondents' postcode locations to be ordered in such a way that they were spread both socio-economically and also geographically in proportion to the number of households in each standard region.

8 We also compared our sample composition with results from several large-scale national surveys commonly used for this purpose in academic studies (Regional Trends, 2001, Vol.36; Annual Abstract of Statistics, 2002, Vol. 138; The Labour Force Survey, 2001). Our unweighted survey results for gender, social class and region/nationality broadly match the distributions reported across the country, indicating that we can have confidence in the representativeness of our sample results.

9 In order to conduct the analyses these socio-economic variables were coded as binary variables. The direction of the coding in each analysis is detailed in Table 1. For example in Table 1 in the 'Interest' model, 'Sex' is coded in terms of 'Being male' where a score of 0 indicates the respondent is female and where 1 indicates the respondent is male. Therefore a positive relationship indicates that males are more likely to show political engagement.

10 See for instance: Butler and Stokes (1974), Parry et al. (1992).

11 The Social trust variable is based on two questions. Firstly, respondents were asked whether they considered that most people could be trusted, and, secondly, whether they felt that most people with 
whom they came into contact would try to take advantage of them or not. It is coded as a binary variable, and the coding direction is detailed in Table 1 in the same way as the socio-economic variables.

12 This independent variable, Associational membership is based on two items taken from the questionnaire-whether or not respondents had previously volunteered to get involved in local or community affairs (like a local community association, a charity, or a sports club), and, if so, how active they had been? It is coded as a binary variable with 1 representing some participation in voluntary activities and 0 representing no such voluntary activity.

13 These dependent variables were developed from our research questions listed earlier. The first dependent variable is Political engagement labelled as 'Interest' which combines two questions - whether respondents had an interest in politics, and whether they were interested in the 2001 General Election (coded as 1 interested/0 not interested). The second dependent variable is Support for the democratic process labelled as 'Democracy' which is a single variable that compares those who are on the whole satisfied or dissatisfied with the way that democracy works in this country. The third dependent variable is Political efficacy labelled as 'Efficacy' which combines whether they considered that being active in politics is a good way to get help for themselves and their family, whether they disagree that it takes too much time to be active in politics and public affairs, whether they disagree that young people like themselves have no say in what the government does, whether they disagree that there aren't enough opportunities for young people like themselves to influence political parties, and also how much influence they consider that they have on the decisions affecting them taken by politicians. This variable is coded as 1 participation opportunities exist/0 no participation opportunities exist. The final dependent variable is Perception of political parties and professional politicians which combines 14 questions concerning whether they agree or disagree that: there is often a big difference between what a party promises it will do and what it actually does when it wins an election; political parties are more interested in winning elections that in governing afterwards; the main political parties in Britain don't offer voters real choices in elections because their policies are pretty much all the same; political parties do more to divide the country than unite it; political parties spend too much time bickering with each other; parties generally do a good job in finding suitable people to run for parliament; in elections, political parties don't tell people about the really important problems facing the country; it's embarrassing when the parties try to appeal to young people during election campaigns; political parties do a good job of listening to young people's concerns, and then responding to them positively; governments don't really care what young people like me think; those elected to parliament soon lose touch with people; parties are only interested in people's votes, not in their opinions; there aren't enough opportunities for young people like me to influence political parties; political parties aren't interested in the same issues that concern young people. This variable is coded 1 enthusiastic/0 not enthusiastic.

14 Tests of multicollinearity between the predictor variables were conducted in multiple regressions. There was no significant multicollinearity between any of the predictors.

\section{References}

Butler, D. and Stokes, D. (1974), Political Change in Britan, London: MacMillan.

Cole, M. (1997), 'Politics and youth', Politics Review, 6, 3, February: 5-9.

Coleman, J.S. (1988), 'Social capital in the creation of human capital', American Journal of Sociology, 94, 95-119.

Electoral Commission (2005a), Election 2005: Turnout, How Many, Who and Why? London: The Electoral Commission.

Electoral Commission (2005b), Social Exclusion and Political Engagement, London: The Electoral Commission.

Electoral Commission and the Hansard Society (2006), An Audit of Political Engagement 3, London: The Electoral Commission and the Hansard Society.

Fahmy, E. (2004), Youth, Social Capital and Civic Engagement in Britain: Evidence from the 2000/01 General Household Survey, London: Office of the Deputy Prime Minister. 
Foley, M. and Edwards, B. (1996), 'The paradox of civil society', Journal of Democracy, 7, 3, 38-52.

Franklin, M.N. (2004), Voter Turnout and the Dynamics of Electoral Competition in Established Democracies since 1945, Cambridge: Cambridge University Press

Hall, P. (1999), 'Social Capital in Britain', in British Journal of Political Science, 29, 417-461.

Halpern, D. (1999), 'Moral Values, social trust and inequality - can values explain crime?', British Journal of Criminology, 41, 236-251.

Heath, A. and Park, A. (1997), 'Thatcher's children?', in R. Jowell, J. Curtice, A. Park, K. Thomson and L. Jarvis (eds), British Social Attitudes: The 14th Report. The End of Conservative Values?Aldershot: Ashgate.

Henn, M., Weinstein, M. and Forrest, S. (2005), 'Uninterested youth? Young people's attitudes towards party politics in Britain', Political Studies, 53, 3, 556-578.

Henn, M. and Weinstein, M. (2006), 'Young people and political (in)activism: why don't young people vote?', Policy and Politics, 34, 3, 517-534.

Jowell, R. and Park, A. (1998), Young People, Politics and Citizenship: A Disengaged Generation? London: Citizenship Foundation.

Leighley, J.E. (1995), 'Attitudes, opportunities and incentives: a field essay on political participation', Political Research Quarterly, 48, 1, 181-209.

Lowndes, V. and Wilson, D. (2001), 'Social capital and local governance: exploring the institutional design variable', Political Studies, 49, 629-647.

Newton, K. (1999a), 'Social and political trust in established democracies', in P. Norris (ed.), Critical Citizens: Global Support for Democratic Governance, Oxford: Oxford University Press, pp. 169187.

Newton, K. (1999b), 'Social capital and democracy in modern Europe', in J. van Deth et al. (eds), Social Capital and European Democracy, London: Routledge.

Norris, P. (2003), 'Young people and political activism: from the politics of loyalties to the politics of choice?', Paper presented to the Council of Europe Symposium, Young People and Democratic Institutions: From Disillusionment to Participation, Strasbourg, 27-28 November 2003.

Office for National Statistics (2001), Labour Force Survey, London: The Stationery Office.

Office for National Statistics (2001), Regional Trends, 36, London: The Stationery Office.

Office for National Statistics (2002), Annual Abstract of Statistics, 138, London: The Stationery Office.

Oppenheim, A.N. (1992), Questionnaire Design, Interviewing and Attitude Measurement, London: Continuum.

O'Toole, T., Lister, M., Marsh, D., Jones, S. and McDonagh, A. (2003), 'Tuning out or left out? Participation and non-participation among young people', Contemporary Politics, 9, 1, 45-61.

Park, A. (2000), 'Young people and political apathy', in R. Jowell, J. Curtice, A. Park, K. Thomson, L. Jarvis, C. Bromley and N. Stratford (eds), British Social Attitudes: The 16th Report. Who Shares New Labour Values? Aldershot: Ashgate.

Parry, G., Moyser, G. and Day, N. (1992), Political Participation and Democracy in Britain, Cambridge: Cambridge University Press.

Pattie, C., Seyd, P. and Whiteley, P. (2003), 'Citizenship and civic engagement: attitudes and behaviour in Britain', Political Studies, 51, 443-468.

Pattie, C., Seyd, P. and Whiteley, P. (2004), Citizenship in Britain: Values, Participation and Democracy, Cambridge: Cambridge University Press.

Phelps, E. (2004), 'Young citizens and changing electoral turnout, 1964-2001', The Political Quarterly, $75,3,238-248$.

Phelps, E. (2005), 'Young voters at the 2005 Britain general election', in The Political Quarterly, 76, 4, $482-87$.

Pirie, M. and Worcester, R. (1998), The Millennial Generation, London: Adam Smith Institute.

Pirie, M. and Worcester, R. (2000), The Big Turn-Off: Attitudes of Young people to Government, Citizenship and Community, London: Adam Smith Institute.

Power Inquiry (2006), Power to The People, York: The Power Inquiry. 
Putnam, R.D. (1993), Making Democracy Work: Civic Traditions in Modern Italy, Princeton, NJ: Princeton University Press.

Putnam, R. D. (1995), 'Tuning in, tuning out: the strange disappearance of social capital in America', Political Science and Politics, 28, 664-683.

Putnam, R.D. (2000), Bowling Alone: The Collapse and Revival of American Community, New York: Simon \& Schuster.

Russell, A., Fieldhouse, E., Purdam, K. and Kalra, V. (2002), Voter Engagement and Young People, London: The Electoral Commission.

Verba, S. and Nie, N. (1972), Participation in America: Political Democracy and Social Equality, New York: Harper \& Row.

Verba, S., Schlozman, K.L. and Brady, H.E. (1995), Voice and Equality: Civic Voluntarism in American Politics, Cambridge, MA: Harvard University Press.

Weinstein, M. (2005), 'A comparative analysis of youth activism in mainstream political parties and social movements in Britain', unpublished Ph.D. thesis, Nottingham Trent University, Nottingham.

White, C., Bruce, S. and Ritchie, J. (2000), Young People's politics: Political interest and engagement amongst 14- to 24-year-olds, York: Joseph Rowntree Foundation.

Whiteley, P., Clarke, H., Sanders, D. and Stewart, M. (2001), 'Turnout', in P. Norris (ed.), Britain Votes 2001, Oxford: Oxford University Press.

Wring, D., Henn, M. and Weinstein, M. (1999), 'Young people and contemporary politics: committed scepticism or engaged cynicism?', in J. Fisher, P. Cowley, D. Denver and A. Russell (eds), British Elections and Parties Review, Vol. 9, London: Frank Cass Publishers. 